\title{
Emergent anthropologies
}

\author{
Douglas R. Holmes
}

In my work with George Marcus we have sought to develop a particular design of and for anthropological projects that allows ethnography to operate as a means to engage analytical perspectives in the making, perspectives that take form prospectively, perspectives that seek to shape contingencies in, of, and about the future. What this demands is that we build our ethnographic project within pre-existing and/or emerging experiments pursued by our subjects. It further requires that we draw on a range of intellectual modalities that intersect, overlap, or are entirely indistinguishable from "ethnographic" method operating within technocratic and scientific settings. In other words, we seek to enter settings in which the "subjects" themselves experiment creatively with the intellectual exigencies of ethnography.

"Inside bureaucracies and policy-making circles of various kinds are contests over interpretations of emerging realities ... perspectives are in play that parallel the curiosities of ethnographers in particularities, the conditions of lived ordinary experience, and a sensitivity to the rules of informal culture that dominate governing rationalities and formalisms. Therefore, there is little demand for ethnography itself to duplicate, or to operate independently of these para-ethnographic tendencies and desires. ... Ethnography advances today by deferring to, absorbing, and being altered by found reflexive subjects-by risking collaborative encounters of uncertain outcomes for the production of ethnographic knowledge" (Holmes and Marcus 2008: 84).

We have shied away from claiming that this agenda constitutes a unified research program or broad disciplinary schema. On the contrary, we have sought to emphasize the remarkable and still underdeveloped potentials of ethnography to underwrite methodologically a continual generation of new disciplinary possibilities and, thus, the propagation of new anthropologies.

"Most contemporary ethnographic projects face in their formative moments a distinctive conundrum. The long-established anthropological archive does little in the way of providing access and, in fact, may frustrate entry to the kind of ethnographic settings that many of us now seek to explore: epistemic communitiesin which 'research,' broadly conceived, is integral to the function of these communities. The science lab serves as the paradigmatic example, but we think that an experimental ethos is now built into the structure of the contemporary and manifest in countless settings, ranging from alternative art spaces to central banks, from communities of climate scientists to communities of Catholic political activists. The expert, and the culture of expertise that she inhabits, is a preferred subject and milieu of contemporary ethnographic inquiry, because within them emergent social and cultural forms are being devised and enacted" (Holmes and Marcus 2008: 82). 
In the example I develop economic actors cultivate an experimental ethos focused not on the lab, but performed in situ, within and across the economy at large.

"These experimental activities are research activities in the sense that they aim at observing and representing economic objects, but alsoand quite explicitly-in the sense that they seek to intervene on these economic objects: to seize them, to modify and then stabilize them, to produce them in some specific manner. To experiment is to attempt to solve a problem by organizing trials that lead to outcomes that are assessed and taken as starting points for further action. Experimentation is action and reflection" (Muisesa and Callon 2007: 163).

The experimental ethos that operates within these cultures of expertise has a relentless character; analytical insights are in motion, they are continuously refined in order to address the shifting nature of various phenomena, and this is where we position our ethnography and align our inquiry (Rheinberger 1997). Rather than discuss these issues in the abstract, I turn to extended example drawn from my own research on central banking. The broad premise of this kind of research is that within diverse cultures of expertise, actors are framing and pursuing robust "anthropological" experiments.

Central bankers are members of an elite group of government appointees numbering no more than a few dozen globally. The voting members of the monetary policy committees (MPCs), the officials charged with determining monetary policy of their respective central banks, are the individuals typically identified as "central bankers." For the purposes of my research I have expanded this group to include other senior officials who participate in policy deliberations, but are not necessarily voting members of MPCs. These include senior members of the research staff, notably those who manage forecasting models that inform policy decisions, as well as the bank personnel charged with communicating monetary policy to the financial markets and to the public. I also include members of an intermediary group of academics as well as networks of observers in business, finance, and journalism that can influence and interpret the data brought to bear on the formulation and communication of monetary policy.

\section{Expectations}

Many years ago I examined the economic dilemmas and cultural predicaments that had for centuries circumscribed the lives of a rural population in northeast Italy. During this work I encountered a question that perplexed my subjects and continues to perplex me. These rural folk, descendents of peasants-who had lived for roughly a thousand years under a profoundly cruel and unjust agrarian system-had undergone a change in outlook. They became in the latter part of the twentieth century susceptible to a very unpeasant-like sentiment. To their surprise, and to mine, they were experiencing something that might be construed as "hope," if not, “optimism” (Holmes 1989; Miyazaki 2004).

The future no longer loomed merely as a matter of dread and despair; it had become for these people a subject with discernable features upon which to reflect and act. This curious shift in sentiments and expectations about the future set the course of my research to some of the most complex technocratic institutions in the world-central banks.

In broadest terms my research examines how central banks endow the future with discernable features and how these institutions underwrite representations of the future with faith and credit. In other words, I am interested in how the economy is modeled linguistically and hence communicatively. How the economy can and must be understood as communicative action, which is performed socially and enacted prospectively.

To do this I have aligned my project with a series of experiments-known cumulatively and, rather prosaically, as "inflation-targeting"-by which these institutions recruited the public to become, as it were, central bankers unto themselves. These experiments-initially designed 
and formalized as policy by the Reserve Bank of New Zealand-seek to influence future sensibilities. Not merely sensibilities about the future but also sensibilities in the future to shape the expectations that impel the most fundamental dynamic of market economies: the evolution of prices (Fligstein 2001; Woodford 2003). The bridge to the ephemera of expectations, to sensibilities in the future is constructed in part with language, through the technical modeling of what I have termed an "economy of words" (Holmes 2009).

The logic guiding these experiments goes like this: If the behavior of prices is "expectational"-as Irving Fisher, J.M. Keynes, and Knut Wicksell proposed in the 1920s-then an anticipatory policy that projects central bank action into the future becomes a means to influence these sentiments (Woodford 2003). As "economic agents"-that is, you and I-assimilate policy intentions as our personal expectations, we do the work of the central bank (Orphanides and Williams 2007).

The instruments developed to manage expectation consist of official statements-typically running fewer than 500 words - that the major central banks of the world publish every four to six weeks in support of their interest rate decisions: decisions that can stimulate, retard, or leave unchanged the pacing of economic activity.

These "econometric allegories," as Alan Blinder and Ricardo Reis (2005) term them, draw on the full intellectual resources of these institutions-the research acumen, the judgment, and the experience of its personnel. They project a forecast of economic and financial conditions over a time horizon of approximately two years along with an explanation of how the respective bank's interest policy will maintain consumer prices within an inflation target range of 1 to 3 percent (or around a single target, typically of 2 percent). A group of key theorists define the elements of this experiment as follows:

"Inflation targeting is a framework for monetary policy characterized by the public announcement of official quantitative targets (or target ranges for the inflation rate over one or more time horizons, and by explicit acknowledgement that low, stable inflation is monetary policy's primary long run goal. Among other important features of inflation targeting are vigorous efforts to communicate with the public about the plans and objectives of the monetary authorities, and in many cases, mechanisms that strengthens central bank's accountabilities for attaining those objectives" (Bernanke et al 1999: 4).

My research is primarily concerned with the continuous creation of econometric allegories-relentlessly and rigorously mediated by data-and how they impart those sentiments and expectation that sustain the inflation-targeting regime (Smart 1999, 2006). Here is an example; an excerpt, composed in the restrained prose of the Federal Open Market Committee, dated 23 September 2009.

"Conditions in financial markets have improved further, and activity in the housing sector has increased. Household spending seems to be stabilizing, but remains constrained by ongoing job losses, sluggish income growth, lower housing wealth, and tight credit. Businesses are still cutting back on fixed investment and staffing, though at a slower pace; they continue to make progress in bringing inventory stocks into better alignment with sales. Although economic activity is likely to remain weak for a time, the Committee anticipates that policy actions to stabilize financial markets and institutions, fiscal and monetary stimulus, and market forces will support a strengthening of economic growth and a gradual return to higher levels of resource utilization in a context of price stability" (http:// www.federalreserve.gov/newsevents/press/ monetary/20090923a.htm).

As we incorporate these statements of policy intentions as our personal expectations, we do the work of the central bank. As our expectations about prices become "anchored" by virtue of these econometric allegories we adjust our practices and thereby participate in the general development of consumer prices in the future. 
These narratives articulated in concert with open market operations-the purchase and sale of government securities by which money is supplied or withdrawn from the economy-are the main tools of monetary policy (Bernanke and Mishkin 1997; Singleton with Grimes, Hawke, and Holmes 2006).

I was fortunate to be in a position to observe the articulation of these econometric allegories during a particularly tumultuous period in the history of central banking, a time when shaping public expectations was crucial. I examined the distinctive and perhaps unlikely sources of these narratives, which, in turn, provide access to the intellectual regimes that define the dayto-day operation of these institutions. I also demonstrate how they serve as instruments of far-reaching experiments in formulation and communication of monetary policy demarking the communicative imperatives that have sustained a "quiet revolution" in the practices of central banking (Blinder 2004). My thesis here is that these statements are not merely expressing an interpretative account or commentary: they are making the economy as a communicative field and as an empirical fact (Holmes 2009).

\section{Quiet revolution}

I became interested in central banks in the early 1990s, around the time the Maastricht Treaty was being finalized and signed, creating the European Union. I was struck by the few paragraphs of the Treaty that proposed the creation of a monetary authority to manage a new and, at the time, unnamed currency. This goal of European Monetary Union, arguably the most radical agenda of the Treaty, had by 1999 yielded a new institution, the European Central Bank (ECB), charged with managing monetary affairs of what became the euro. My interest in the European Central Bank and the Deutsche Bundesbank, which is now an integral part of the $\mathrm{ECB}$, has since expanded to include the Reserve Bank of New Zealand (RBNZ), the Sveriges Riksbank, and the Bank of England. In the background of the study is an ongoing assessment of the policies and practices of the US Federal Reserve System.

Drawing on Alan Blinder's insights on the revolutionary changes that these institutions have undergone I have framed my work as an ethnographic account. An account not of a central bank or of central banking per se, but of how famously secretive institutions that were in some notable cases committed to a mystique of secrecy as vital to their function, began to experiment with far-reaching communicative practices under the aegis of transparency (Blinder 1998, 2004; Blinder et al. 2008). Crucially, this is not a matter of merely informing the market and the public about central bank policies and practices, nor should it be mistaken for a conventional informational or public relations function of a government bureau or agency, rather these communications are the instruments of policy themselves.

Blinder (2009) has reviewed some key elements of the revolution. He began by quoting Karl Brunner's acerbic depiction of the old regime of central bank communications. "Central Banking ... thrives on a pervasive impression that [it] ... is an esoteric art. Access to this art and its proper execution is confined to the initiated elite. The esoteric nature of the art is moreover revealed by an inherent impossibility to articulate its insights in explicit and intelligible words and sentences" (Brunner 1981, quoted in Blinder 2009: 1).

Blinder then reviewed his own interventions, drawn from his 1996 Robbins lectures at the London School of Economics, in which he alludes to possibility of orchestrating central bank communication in a manner that engages the reflexive capacities of economic actors:

"Greater openness might actually improve the efficiency of monetary policy ... [because] expectations about future central bank behaviour provide the essential link between short rates and long rates. A more open central bank ... naturally conditions expectations by providing the markets with more information about its own view of the fundamental factors guiding monetary policy ..., thereby creating a virtuous 
circle. By making itself more predictable to the markets, the central bank makes market reactions to monetary policy more predictable to itself. And that makes it possible to do a better job of managing the economy" (Blinder 1998: 70-72).

The third element of this abbreviated history of central bank innovation is Michael Woodford's (2003) assertion that the essence of monetary policy is the art of managing expectations:

"Successful monetary policy is not so much a matter of effective control of overnight interest rates ... as of affecting ... the evolution of market expectations ... [Therefore,] transparency is valuable for the effective conduct of monetary policy" (quoted in Blinder 2009:1 ).

While expressing caution about Woodford's position Blinder summarizes the revolutionary significance of these ideas on the practices of central banking.

"These new ideas from the academy had major impacts on actual central banking practice. Even the Federal Reserve, where then-Chairman Alan Greenspan once prided himself on 'mumbling with great incoherence,' has been increasing its communicativeness incrementally since 1994 . And the Fed is far from a leader in this regard. Indeed, one might argue that the European Central Bank (ECB) has been more transparent than the Fed ever since it opened for business. The Reserve Bank of New Zealand and the Bank of England were early and enthusiastic converts to greater transparency and remain among the leaders in that regard, although Norges Bank and Sveriges Riksbank may now be in the vanguard. And there are many other examples. The attitudes that Brunner parodied have been put to rout" (2009: 1).

In the late 2008 during a brief visit to the RBNZ, I noticed a modest terminological distinction-people were referring to the "framework" rather than to the "inflation-targeting framework." I had always thought the former term was just shorthand for the latter and did not pay it much attention. However, in the midst of the financial tumult that ensued after the collapse of Lehman Brothers in mid-September 2008 this terminological shift became significant. Inflation-targeting emerged as a far broader framework for addressing acute analytical problems-not merely inflation-that challenged fundamental conventions of monetary economics, notably it provided the communicative instruments for recruiting the public to participate in the labor of resolving the unfolding crisis (Krugman 1998, 2007; Svennson 2003, 2009a, 2009b).

In the first instance I am committed to portraying the operation of central banks from the perspective of the personnel working within these institutions in their own terms and in their analytical patois. I am particularly interested in portraying the experimental ethos that informs the work of these institutions, the nature of data, and the generation of analytical insights. These figures are keenly aware of these experiments mediated by a reflexive use of language. One can find, for example, books by Deirdre McClosky on the rhetorical nature of economics on the shelves or desks of interested readers in central banks. But, as I have already suggested, I am also interested in deeper cultural issues at stake in this revolution that exceed the concerns of optimal monetary policy. Centrally, I am interested in how the economic allegories designed to shape public expectations also addressed reciprocally the power and limitation of data and the vulnerabilities of a world that depends for its operation on the information that can or cannot be gleaned from data (Keynes 2007).

\section{On the road}

Questions about the nature of data shaped many aspects of my ethnographic approach serving as the bridge to the intellectual labor performed by my subjects. Indeed, I found that my own intellectual practices were fully implicated in what I was studying. Specifically, I observed how "ethnographic" modalities were assimilated 
within these technocratic settings in which the "subjects"-central bankers-experiment creatively with the exigencies of ethnography.

For example, Timothy Besley (2009), while he was a member of the Monetary Policy Committee (MPC) of the Bank of England, drew attention explicitly to the complementary relation between the intellectual practices of anthropologists and central bankers.

"Well you know I spend a lot of my time, and it is one of the great pleasures of being on the MPC, talking to businesses. Only last week I was out on the road 40 or 50 miles away from London talking to a number of businesses and it is really interesting when you kind of, if you like, almost take the anthropological approach, to the global crisis. You sit down perhaps with an entrepreneur, someone who is in a small business, could be a midsize business and they give you their own window on the global crisis and what is interesting about that is that each of them will have their own particular story of how it is hitting them. And while in the end we talk of these big macro trends it is really pretty fascinating to see how it plays out in a particular context. One thing you quickly learn there is no single model of how the global crisis is evolving at that micro level even though the big picture trends are familiar."

He then made an ethnographic assertion, noting that during his sojourns in the field what he was able to observe was the ebbs and the flows of what he termed the "currency of confidence," a phenomenon that was not fully or necessarily evident from his purview as an economist. "We hear time and time again the currency of confidence is hugely important to people who run businesses. Something I perhaps learned as an economist, we do talk about animal spirits and we talk about the psychology of confidence but something I guess I hadn't quite appreciated as much as I do now as I go on the road" (Besley 2009).

Besley thus recounts his engagement with another dimension of the communicative practices that imbue central banking with an analyt- ical language — a natural language — that imparts contexts, and that informs the sensibilities and expectations that can impel economic activity in the future. More important, he is drawing on the intellectual acumen of situated actors in businesses across the UK to inform acute representations of the economy capturing its microfoundational dynamics rooted in learning and in experience. Crucially, he is not invoking an anthropological purview to illustrate an idiosyncratic practice of the Bank of England, but its core concern: the dynamics of confidence. Thus, an engaged and sophisticated ethnographic practice-theoretically informed-was operating in the scene of fieldwork independent of my project. I was thus able to orient my work in a manner that drew fully on the collaborative possibilities offered by this salutary coincidence and convergence.

It is fair to say that my project spans a period of unusual financial turmoil beginning in the aftermath of $9 / 11$ and continuing during the course of the first decade of the new century. The key issues at stake in the project were unexpectedly amplified and ratified at every turn during the decade by exigent circumstances that my subjects or I could not have foreseen. The technocratic innovations that impelled the revolution that is the subject of my research were recast as the basis for contextualizing the tumultuous conditions analytically and the formulation of policy to influence the severity, the breadth, and the duration of the destructive storm.

\section{Public currency}

What is at stake in the cumulative experiments pursued by central banks? Mervyn King, governor of the Bank of England, broached what I think is a significant shift in the nature of currency and specifically, the emergence of what he termed (in passing) a "public currency" (2004). Complex communicative practices-mediated by continuous experimentation and learningunderwrite this public currency at a time when a simple governmental "fiat" is no longer sufficient or, perhaps, plausible: 
"With paper money intrinsically almost worthless, what then determines whether a loaf of bread is worth one dollar or three dollars? The short answer, sweeping a lot of complications under the rug, is that in a paper-money system there is a need for some additional constraint on monetary policy, called a nominal anchor, to tie down the price level to a specific value at a given time. ... An effective commitment to long-run price stability is just such a nominal anchor, since (given the current level of prices), a target rate of inflation communicates to the public the price level the central bank is aiming to achieve at specified dates in the future" (Bernanke et al. 1999: 19-20).

The nominal anchor that Bernanke and his colleagues are referring to represents a radical abstraction of a vastly more complex intellectual and monetary regime that links the soundness of a currency directly to sentiments and expectations of the public, expectations and sentiments explicitly about the future that are modeled linguistically and communicatively.

Furthermore, these experiments demand a revision of our understanding of the capacities of economic actors. From the standpoint of these institutions and specifically, their monetary policy framework, economic actors must be viewed in relationship to a range of reflexive capabilities (Lucas 1986). Above all, these actors can learn. The communicative strategies of central banks assume that these protagonists can model the economy "in the wild" and their expectations can be shaped by socially mediated knowledge.

In other words, models proliferate: some are attuned to the financial press that reports on those monetary scenarios that emanate from central banks, while others are aligned with analyses of government and private sector economists. Expectations can be modeled in relation to astute political commentaries that evaluate alternative economic scenarios. They can be further informed by the "deep articulations" in which networks of interlocutors continually create metaphors and exchange stories. These protagonists learn from employers and employees, from union representatives and managers, from co-workers, friends, and acquaintances. They pursue their modeling of economic conditions in dark corners of local pubs and in meeting halls of dairy cooperatives. They can learn from suppliers, from clients, from sales representatives. Above all, they experience pricing first-hand in their grocery bills, in their mortgages, in their budgeting of income and expenditures for households and firms. They assimilate "folk variants" of economic theory that speak with metaphorical, if not mathematical, precision to their economic circumstances and to their existential struggles. They create models in real time drawn from experience, allowing them to make inferences about their future. It is by virtue of this learning and of this modeling that they participate in the creation of the economy as social facts, which can be engaged from countless perspectives and acted upon in innumerable ways. By so doing, these actors, these protagonists enliven a public currency (Abolafia 1998; Callon 2007; Granovetter 1985; Graeber 2001; MacKenzie et al. 2006; Riles 2001, 2004, 2006).

\section{Conclusion}

This article has demonstrated how intricate aspects of a monetary regime are mediated by analytical modalities that intersect, overlap, or are entirely indistinguishable from ethnographic methods. I have been particularly struck with how the personnel of central banks experiment creatively with the intellectual possibilities of ethnography, and how their practices reveal the still underdeveloped potentials of ethnography to sustain methodologically a continual generation of new disciplinary agendas and, thus, the propagation of new anthropological problems and perspectives.

\section{Acknowledgments}

Fieldwork for this research was funded by a grant from the Wenner-Gren Foundation. 
Douglas R. Holmes's current fieldwork focuses on the intellectual regime that informs contemporary practices of central banking. He is continuing his work on European identities, analyzing how the EU imparts to its citizens the distinctive challenge and the ambiguous burden of continually negotiating the cognitive meanings and the political exigencies of a pluralist Europe. His publications include Integral Europe: Fast-Capitalism, Multiculturalism, Neofascism (2000).

E-mail: dholmes@binghamton.edu.

\section{References}

Abolafia, Mitchel Y. 1998 Markets as cultures. In The laws of the markets, ed. Michael Callon, 69-85. Oxford: Blackwell.

Besley, Timothy. 2009. "BOE's Besley says control of public finances is "what counts,"” Interview with Tom Keene, 26 May, http://media.bloomberg .com/vC7PELMDwzuQ.mp3, accessed June 23, 2009.

Bernanke, Ben, and Fredric Mishkin. 1997. Inflation Targeting: A new framework for monetary policy. Journal of Economic Perspectives 11 (2): 97116.

Bernanke, Ben, Thomas Luabach, Fredric S. Mishkin, Fredric, and Adam S. Posen. 1999. Inflation Targeting: Lessons from the International Experience. Princeton: Princeton University Press.

Blinder, Alan S. 1998 Central banking in theory and practice. Cambridge: MIT Press.

. 2004. The quiet revolution. New Haven: Yale University Press.

- 2009. Talking about monetary policy: the virtues (and vices?) of central bank communication. Working Papers 274, Bank for International Settlement, Basel.

Blinder, Alan S., Jakob de Haan, Michael Ehrmann, Marcel Fratzscher, and David-Jan Jansen. 2008. What we know and what we would like to know about central bank communication. Vox: Research-Based Policy Analysis and Commentary from Leading Economists, May 15. www.voxeu.org/index.php?q=node/1143.

Blinder, Alan, and Ricardo Reis. 2005. The Greenspan standard. Paper presented at the Federal
Reserve Bank of Kansas City Symposium, Jackson Hole, Wyoming, 25-27 August.

Callon, Michel. 2007. Performative economics. In Do economists make markets? ed. Donald MacKenzie, Fabian Muniesa, and Lucia Siu, 311-57. Princeton: Princeton University Press.

Fligstein, Neil. 2001. The architecture of markets: An economic sociology of twenty-first-century capitalist societies. Princeton: Princeton University Press.

Graeber, David. 2001. Toward an Anthropological Theory of Value: The false coin of our dreams. New York: Palgrave.

Granovetter, Mark. 1985. Economic Action and Social Structure: The problem of embeddedness. American Journal of Sociology 91 (3): 481-510.

Holmes, Douglas R. 1989. Cultural disenchantments: Worker peasantries in northeast Italy. Princeton: Princeton University Press.

- 2009. Economy of words. Cultural Anthropology 24 (3): 381-419.

Holmes, Douglas R., and George E. Marcus. 2008. Collaboration today and the re-imagination of the classic scene of fieldwork encounter. Collaborative Anthropologies 1: 136-70.

Keynes, John Maynard. 2007. The general theory of employment, interest and money. Basingstoke, UK: Palgrave.

King, Mervyn. 2004. The institutions of monetary policy. American Economic Review Papers and Proceeds 94 (2): 1-13.

Krugman, Paul. 1998. It's baaack: Japan's slump and the return of the liquidity trap. Brookings Papers on Economic Activity 49: 137-206.

- 2007. Introduction. In Keynes, The general theory of employment, interest and money, xxvxxxviii.

Lucas, Robert, Jr. 1986. Adaptive behavior and economic theory. Journal of Business 59: 401-26.

MacKenzie, Donald, Fabian Muniesa, and Lucia Siu. 2006. Introduction. In Do economists make markets? ed. Donald MacKenzie, Fabian Muniesa, and Lucia Siu, 1-19. Princeton: Princeton University Press.

Miyazaki, Hirokazu. 2004. The method of hope: Anthropology, philosophy, and Fijian knowledge. Stanford: Stanford University Press.

Muisesa, Fabian, and Michel Callon. 2007. Economic experiments and the construction of markets. In MacKenzie et al., Do economists make markets? 163-89.

Orphanides, Athanasios, and John C. Williams. 2007. Robust monetary policy with imperfect 
knowledge. Journal of Monetary Economics 54: 1406-35.

Rheinberger, Hans-Jorg. 1997. Toward a history of epistemic things: Synthesizing proteins in the test tube. Stanford: Stanford University Press.

Riles, Annelise. 2001. Real-time: Governing the market after the failure of knowledge. Paper presented at the University of California at Berkeley, 18 January.

- 2004. Real time: Unwinding technocratic and anthropological knowledge. American Ethnologist 31 (3): 392-405.

- 2006. Introduction. In Documents: Artifacts of modern knowledge, Annelise Riles, 1-38. Ann Arbor: University of Michigan Press.

Singleton, John, with Arthur Grimes, Gary Hawke, and Frank Holmes. 2006. Innovation and independence: The reserve bank of New Zealand. Auckland: Auckland University Press.

Smart, Graham. 1999. Storytelling in a central bank:
The role of narrative in the creation and use of economic knowledge. Journal of Business and Technical Communication 13: 249-73.

. 2006. Writing the economy: activity, genre and technology in the world of banking. London: Equinox.

Svensson, Lars E. 2003. Escaping from a liquidity trap and deflation: The foolproof way and others. Journal of Economic Perspectives 17 (4): 145-66.

2009a. Monetary policy with a zero interest rate. Speech delivered at the Sveriges Riksbank, Stockholm, Sweden, 17 February.

- 2009b. Flexible inflation targeting: Lessons from the financial crisis. Speech delivered at the Sveriges Riksbank, Stockholm, Sweden, 21 September.

Woodford, Michael. 2003. Interest and Prices: Foundations of a theory of monetary policy. Princeton: Princeton University Press. 